\title{
Employee Engagement as a Rhizome for Talent Retention
}

\author{
Esther Zionia.A, Sathyapriya.J
}

\begin{abstract}
In this modernized era, every country competes with one another in their economic growth. In the phase of developing economic growth, IT/ITES Sector plays a major role. In a country every organization battle with one another to acquire talented employees and retain them. Retaining talented employees become a threat to every organization. Employee engagement is a unique approach to obtain the result of retaining talented employees. In order to be in the number one position, every organization needs support from talented employees who help in brightening the organization. Nowadays unsatisfied talented employees are ready to migrate from one organization to another organization where all the organization is ready to acquire them. This research paper, therefore, identifies the role of employee engagement in Talent Retention at organizations and identifies the relationship between employee engagement and talent retention. To find out the impact of employee engagement on talent retention, Multiple Regression were used and to identify the major programs/activities furnish by employers to retain a talented employee with particular reference to Coimbatore using descriptive survey research design. The research hypothesis was tested using Statistical tools such as Correlation, Multiple Regression, and Weighted Mean Average. 116 respondents were analyzed using a Systematic Random sampling method. The findings revealed that there is a relationship between employee engagement and talent retention. Once employee engagement is good there is a chance of retaining talented employees. Some of the top programs or activities are offered by employers to retain their talented employees are Social Activities, Celebrations, Flexible work schedule, Career planning discussion, Community Outreach program, Team Building Activities, Communication Activities, Orientation Program and Learning \& Skill Enhancement program Hence it is proved that organizational climates drive the talented employees to remain in the organization.
\end{abstract}

Index Terms: Correlation, Employee Engagement, Multiple Regression, Talent Retention

\section{INTRODUCTION}

Talented Employees are the key players of any organization. In today's market place, Employee engagement drives an organization to its success path. Retaining talented employees helps the organization to grow and improve their own career. It is very clear that the Organization nowadays facing a threat in retaining talented employees. Retaining talented employees not only become

\section{Revised Manuscript Received on July 22, 2019.}

Esther Zionia.A, Ph.D. Research Scholar, Department of Management Studies, Periyar Maniammai Institute of Secience \& Technology, Thanjavur, India.

Sathyapriya.J, Associate Professor, Department of Management Studies, Periyar Maniammai Institute of Secience \& Technology, Thanjavur, India. the biggest challenge but engaging them, captivating their hearts and minds of their work plays an indispensable role (Lockwood, 2007). Engaged talented employees are more likely to stay in an organization. Tedious and Repetitious work with no battle is one of the leading reason to drop out of their organization. Retaining talented employees needs an attractive and effective engagement strategy. Employee Engagement is different from Job Satisfaction. Robinson et al., (2004) define employee engagement as the amplification of commitment. Employee Engagement becomes one of the best business management and complex concept which involves many issues of level in engaging talented employees. Employee Engagement is an essential tool to pull the organization towards its success especially engaging talented employees is essential (Tarique \& Schuler, 2010). Engaging a talented employee to an organization helps in inducing an emotional bond and a passionate about their work which results in both retentions of talented employee's and organizational growth. Konrad et al., (2006) states that employee engagement can be the combination of emotional, cognitive and behavioral. Cognitive engagement includes employee thinking and view about the organization and its culture where emotional engagement is totally about the emotional attachment of talented employees with the organization and their peers, colleagues. In another side, behavioral engagement is a crowning factor that shows the effort employee gave to his work, which includes intellectual effort, mental effort and overtime given to particular work. Employee Engagement helps in employee commitment which results in better performance. Harter et al., (2002) reported that organizational performance and its financial performance totally depends on talented employees who are engaged in their works. Preeti (2014) agrees that talented employees with lesser commitment are likely to leave the organization which clearly shows that commitment influences retention which results in good organizational performance. It is clear that acquiring talented employees not the end, retaining them is as important as acquiring them. The organization should concentrate on the strategy to engage the talented employee's. Suhasini (2018) strongly agrees that Engaged employees would be more helpful in achieving organization goal. Sanford(2003) identifies that disengaged employees provoke decreased profits and sales which leads to lower customer satisfaction and productivity. Reducing employee turnover plays a major role in every organization. Employees add value to any organization, especially talented employees. In order to reduce talented employee turnover, employees need to be occupied with some strategy. Here, Employee Engagement plays a key role in retaining talented 
employees. It is mandatory for every organization to implement an employee engagement strategy to keep their talented employees in their own organization.

\section{REVIEW OF LITERATURE}

Seigts et al., (2006) found that some of the factors influencing employee engagement are career development, control over own job, Clarity in communication, Flexibility in work schedules, Performance Clarity and policies.

Buckingham et al., (1999) analyzed pay and benefits, supportive work environment, Recognize \& Encourage innovations, Leadership and good team building are the influencing employee engagement factor in retaining the talented employees.

Thiagarajan \& Renugadevi (2011) conducted a research to find out the employee engagement practices. Interviewed 126 Executives of different BPO Industry and found that Career development, performance appraisal, and motivation factors have a strong connection with employee engagement.

Mamta et al.,(2011) conducted empirical research to find out the factors of employee engagement on talent retention. 84 manager employees results reveal that Job role, Pay and Benefits and Supportive environment are the influencers of employee engagement.

Jyotsna (2007) conducted research on "Talent management strategy of employee engagement in Indian ITES employees: Key to Retention" to find out the programs need to be provided to retain talented employees. From the analysis, it is found that Orientation programs, Learning and skill enhancement programs, and celebration need to be done in every organization in order to retain talented employees.

Otken \& Erbin (2010) investigate the relationship between employee engagement and employee retention. It was found that there is a relationship between employee engagement and employee retention. Recommended practices are Social media engagement, online communication, open house sessions, Internal magazine (or) Newsletter, employee suggestion schemes and satisfaction survey to engage employees in order to retain talented employees.

Knippenberg et al., (2006) explains that the organization needs to develop some strategies in order to retain them. Some of the strategies like Recreational Activities and social activities need to be developed to engage an employee to retain them.

Childs \& Stoeber (2010) interviewed 106 employees and found that Flexible work schedule, Career development, and Rewards help them to remain in their jobs and these play a major role in engaging the employees.

Victor Bart et al (2000) analyzed less job stress lead to retain a talented employee which result in the organization profits and achieving its goals. It was understood that Recreational Activities and Social Activities as a team building spirit need to be included in engaging talented employees.

\section{RESEARCH METHODOLOGY}

\section{A. Research Design}

The descriptive research design was adopted in this study with particular reference to Coimbatore. The sample size was 116 IT/ITES Companies HR Managers. Systematic Random
Sampling technique was used to collect data. The structured questionnaire were used. The secondary data was collected from the previously published records, journals, articles, websites, thesis, e-books, books etc. The questions were framed in 5 points Likert scale method. (5 - Strongly Agree, 4 - Agree, 3 - Partially Agree, 2 - Disagree, 1 - Strongly Disagree).

\section{B. Objectives of the Study}

- To find out the relationship between Employee Engagement and talent retention.

- To find out the impact of Employee Engagement on talent retention.

- To identify the major programs provided to retain the talented employees.

\section{Statistical Tools}

The research objectives were framed with perfect statistical tools to evaluate the prompt results.

\begin{tabular}{|c|l|l|}
\hline S.NO & \multicolumn{1}{|c|}{$\begin{array}{c}\text { DESCRIPTION OF } \\
\text { OBJECTIVES }\end{array}$} & $\begin{array}{c}\text { STATISTICAL } \\
\text { TOOLS FOR } \\
\text { ANALYSIS }\end{array}$ \\
\hline 1 & $\begin{array}{l}\text { The Relationship between } \\
\text { Employee Engagement and } \\
\text { talent retention }\end{array}$ & Correlation \\
\hline 2 & $\begin{array}{l}\text { Impact of Employee } \\
\text { Engagement on talent } \\
\text { retention. } \quad \text { Multiple Regression }\end{array}$ \\
\hline 3 & $\begin{array}{l}\text { Major programs provided to } \\
\text { retain talented employees. }\end{array}$ & $\begin{array}{l}\text { Weighted Average } \\
\text { Rank }\end{array}$ \\
\hline
\end{tabular}

\section{DATA ANALYSIS}

A. Relationship between Employee Engagement and Talent Retention

\begin{tabular}{|ll|l|l|}
\hline \multicolumn{5}{|c|}{ Table 1 } \\
\hline Talent Retention & Pearson & Talent Retention & $\begin{array}{l}\text { Employee } \\
\text { Engagement }\end{array}$ \\
& $\begin{array}{l}\text { Correlation } \\
\text { Sig. (2-tailed) }\end{array}$ & 1 & $.862(* *)$ \\
& $\mathrm{N}$ & 116 & .000 \\
Employee & Pearson & $.862(* *)$ & 116 \\
Engagement & Correlation & .000 & 1 \\
& Sig. (2-tailed) & .000 & 116 \\
& $\mathrm{~N}$ & 116 & \\
\hline
\end{tabular}
(2-tailed).

From the above table 1 , it is clearly understood that correlation of talent retention with itself $(r=1)$, and the number of non-missing observations for talent retention $(n=116)$. Correlation of talent retention and Employee Engagement $(r=0.862)$, based

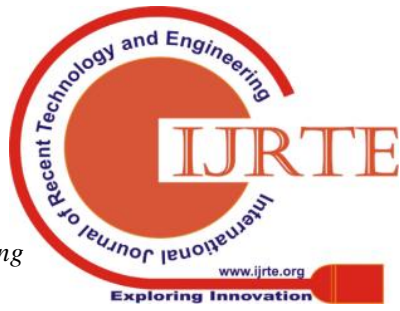


on $n=116$. Significant value is 0.000 which is $<0.005$ and this shows that talent retention and employee engagement have a statistically linear relationship $(\mathrm{P}<.001)$. The direction of the relationship is positive (i.e., talent retention and employee engagement are positively correlated), meaning that these variables tend to increase

together (i.e., the greater the employee engagement greater the talent retention). So there is a strong relationship between employee engagement and talent retention.

B. Impact of Employee engagement on talent retention

Table 2: Model Summary

\begin{tabular}{|c|c|c|c|c|}
\hline Model & $\mathrm{R}$ & R Square & $\begin{array}{c}\text { Adjusted R } \\
\text { Square }\end{array}$ & $\begin{array}{l}\text { Std. The } \\
\text { error of the } \\
\text { Estimate }\end{array}$ \\
\hline 1 & $.916(a)$ & .839 & .824 & .093 \\
\hline
\end{tabular}

a Predictors: (Constant), Flexibility in work schedule, Career Development, Leadership, Work Environment, Performance clarity and feedback, Recognize \& Encourage Innovations, Support enthusiasm in the workplace, Pay and benefits, policies, Team building activities

From the above table 2, Model Summary can be a multiple correlation coefficient. $R$ can be considered to be one measure of the quality of the prediction of the dependent variable (Talent Retention). A value of 0.916 , indicates a good level of prediction. The "R Square" column represents the $R^{2}$ value, which is the proportion of variance in the dependent variable (Talent Retention) that can be explained by the independent variable (Employee Engagement). $R^{2}$ value is 0.839 that our independent variables explain $83.9 \%$ of the variability of the dependent variable (Talent Retention).

Table 3: ANOVA(b)

\begin{tabular}{|c|c|c|c|c|c|c|}
\hline Model & & $\begin{array}{l}\text { Sum of } \\
\text { Squares }\end{array}$ & Df & $\begin{array}{c}\text { Mean } \\
\text { Square }\end{array}$ & F & Sig. \\
\hline & $\begin{array}{l}\text { Regression } \\
\text { Residual } \\
\text { Total }\end{array}$ & $\begin{array}{c}4.773 \\
.917 \\
5.690\end{array}$ & $\begin{array}{c}10 \\
105 \\
115\end{array}$ & $\begin{array}{l}.477 \\
.009\end{array}$ & 54.681 & $.000(\mathrm{a})$ \\
\hline
\end{tabular}

a Predictors: (Constant), Flexibility in work schedule, Career Development, Leadership, Work Environment, Performance clarity and feedback, Recognize \& Encourage Innovations, Support enthusiasm in the workplace, Pay and benefits, policies, Team building activities

b Dependent Variable: Talent Retention

The above table 3, shows that the independent variables statistically significantly predict the dependent variable, $F(10,105)=54.681, p<.0005$ (i.e., the regression model is a good fit of the data).

Table 5

\begin{tabular}{|l|c|c|c|c|}
\hline Model & & $\begin{array}{c}\text { Stand } \\
\text { ardize } \\
\mathrm{d} \\
\text { Coeffi }\end{array}$ & & \\
cients & $\mathrm{t}$ & Sig. \\
\hline
\end{tabular}

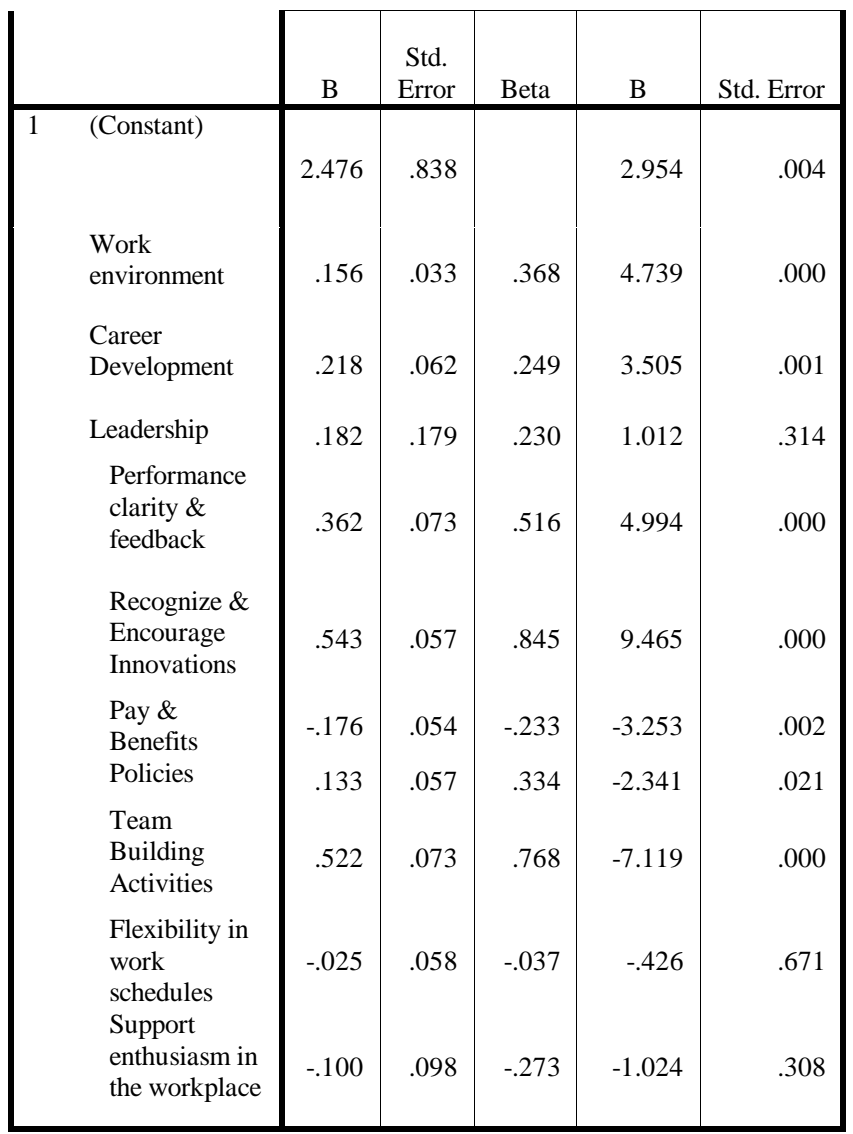

a Dependent Variable: Talent Retention

From the above table 4, explains unstandardized coefficients i.e., B and Std. deviation illustrate how much the dependent variable (Talent Retention) varies with an independent variable(Employee Engagement) when all other independent variables (Work Environment, Career Development, Performance Clarity \& feedback, Recognize \& Encourage Innovations, Pay \& Benefits, Policies, Team Building Activities) are held constant.

A p value of Leadership, Flexibility in work schedules and Support enthusiasm in the workplace is $0.314,0.671 \& 0.308$ $\mathrm{P}$ values is $>0.05$ and hence the null hypothesis was rejected. Leadership, Flexibility in work schedules and Support enthusiasm in the workplace don't have an impact on talent retention.

\section{Multiple Regression equation is:}

Talent Retention $=\mathbf{2 . 4 7 6}+(\mathbf{0 . 1 5 6} *$ Work Environment $)+$ $(0.218 *$ Career Development $)+(\mathbf{0 . 3 6 2} *$ Performance clarity \& feedback $)+(0.543 *$ Recognize \& Encourage Innovations $)-(0.176 *$ Pay \& Benefits $)+(0.133 *$ Policies $)$ $+(0.522 *$ Team Building Activities)

Work Environment, Career Development, Performance Clarity \& feedback, Recognize \& Encourage Innovations, Pay \& Benefits, Policies, Team Building Activities significant value is $<0.05$. Hence accept the alternative hypothesis and it's clear that Employee Engagement (Work Environment, Career Development, Performance Clarity \& feedback, Recognize \& Encourage Innovations, Pay \& Benefits, Policies, Team 
Building Activities) influence Talent Retention.

From the above table 4 , the Beta values pinpoint the order of importance of the independent variables. The variable with the very best Beta worth is that the comparatively most significant variable quantity. On scrutinizing the independent variables in the model, it was found that Recognize \& Encourage innovations made the enormous contribution with the value of 0.845 . It was

followed by the Team Building Activities (Beta=0.768), Performance Clarity \& feedback (Beta=0.516), Work Environment (Beta=0.368), Policies (Beta=0.334) and Career Development (Beta=0.249). Although the contribution made by the independent variables such as Pay and Benefits is significant, they were found to make the smallest contributions to the model with their determination coefficients of -.233 .

\section{MAJOR PROGRAMS PROVIDED TO RETAIN THE TALENTED EMPLOYEES}

Table 5

\begin{tabular}{|c|c|c|c|}
\hline $\begin{array}{l}\text { Employee Engagement } \\
\text { Programs }\end{array}$ & Mean & $\begin{array}{c}\text { Std. } \\
\text { Deviation }\end{array}$ & Rank \\
\hline Coaching \& Mentoring & 4.84 & .364 & VII \\
\hline $\begin{array}{l}\text { Learning \& Skill } \\
\text { enhancement programs }\end{array}$ & 4.95 & .222 & $\mathrm{XV}$ \\
\hline Social Activities & 4.75 & .525 & III \\
\hline Orientation Programs & 4.93 & .254 & XIV \\
\hline $\begin{array}{l}\text { Employee Suggestion } \\
\text { Schemes }\end{array}$ & 4.91 & .284 & XIII \\
\hline Open House Sessions & 4.89 & .317 & XI \\
\hline $\begin{array}{l}\text { Community Outreach (or) } \\
\text { CSR Program }\end{array}$ & 4.86 & .346 & VIII \\
\hline $\begin{array}{l}\text { Internal Magazine (or) } \\
\text { Newspaper }\end{array}$ & 4.91 & .294 & XII \\
\hline Recreational Activities & 4.75 & .558 & II \\
\hline Online Communication & 4.88 & .327 & $\mathrm{X}$ \\
\hline Social Media Engagement & 4.87 & .337 & IX \\
\hline Rewards \& Recognition & 4.74 & .606 & $\mathrm{I}$ \\
\hline Celebrations & 4.83 & .443 & IV \\
\hline Flexible Work Schedules & 4.77 & .424 & $\mathrm{~V}$ \\
\hline Career Planning & 4.81 & .394 & VI \\
\hline
\end{tabular}

\begin{tabular}{|l|l|l|l|}
\hline Discussion & & & \\
\hline Satisfaction Survey & 4.87 & .337 & IX \\
\hline
\end{tabular}

From the above analysis table 5, it can be seen that employers provide Reward \& Recognition in order to engage talented employees as the most preferred activity in retaining a talent (Mean of 4.74). The mean is also comparably high for the Recreational Programs (mean of 4.75) and Social Activities (Mean of 4.75) which falls under II \& III rank. Employers are allowing celebrations like Festival celebration, Birthday Celebration and etc (mean of 4.83) which falls under IV rank. Employers are moderately permitting flexible work schedule in retaining talented employees with the mean of 4.77 which falls under V rank. Employers conduct Career Planning discussion such as Mentoring, Leadership development Activity to retain talented employees (Mean of $4.81 \&$ Mean of 4.84) which falls under VI and VII rank. Employers are providing Community Outreach (or) CSR Programs such as Teaching, Fund Raising and Volunteering for Social Cause in order to achieve team building and culture development activity (Mean of 4.86) which falls under VIII. The mean is also relatively high for Social Media Engagement (mean of 4.87) and Satisfaction Survey (Mean of 4.87) which falls under IX rank. Employers are providing Communication Activities to engage talented employees some of the programs are Online Communication (Mean of 4.88) , Open House Sessions (Mean of 4.89), Internal Magazine (or) Newsletter (Mean of 4.91) and Employee Suggestion Schemes (Mean of 4.91) which falls under $\mathrm{X}, \mathrm{X} 1, \mathrm{X} 11, \mathrm{XIII}$ rank. Every organization gives Orientation program to engage and retain talented employees (Mean of 4.91) which falls under XIV and employers are providing Learning \& Development Program as a Learning \& Skill enhancement programs with the Mean of 4.95 which falls under XV rank to engage a talented employee as a result of retaining them. A standard deviation close to zero indicates that the mean is reliable which there little or no volatility within the sample is. Table shows that the standard deviation for all the factors is a smaller amount than one that indicates that the dispersion of the information is low.

\section{CONCLUSION}

Acquiring a talented employee is one kind of troublesome where retaining them is another kind of ambitious. Once talented employees were retained, organizational growth automatically increases. Engaging the employees are one of good way to maintain a talented employees in an organization. When talented employees are engaged properly, there is a way to retain them in the future. Hence it's clear that Employee Engagement plays a indespensible role in retaining talented employees. This study shows that some of the employers in IT/ITES companies are retaining the top talents using some of the employee engagement strategies. This study found that employee engagement has a good relationship with talent retention i.e., employers can use employee engagement as a strategy to retain top talented employees. Some of the major influencers are Work Environment, Career 
Development, Performance Clarity \& feedback, Recognize \& Encourage Innovations, Pay \& Benefits, Policies, and Team Building Activities to engage talented employees to retain them. This study reveals that providing rewards \& recognition to the talented employees motivate them to do a job which leads to staying in an organization. It was found that an organization should conduct a program in order to engage talented employees which results in retaining them. Recreational Program considered as the most influencing variable in retaining talented employees followed by Social Activities,

Celebrations, Flexible work schedule, Career planning discussion, Community Outreach program, Team Building Activites, Social Media Engagement, Satisfaction Survey, Online Communication, Open House Sessions, Internal Magazine (or) Newsletter, Employee suggestion schemes, Orientation Program and Learning \& Skill Enhancement program. Finally, it is clear that different Advanced Business Management Activities to engage talented employees helps in retaining them, which implicate in creating a good employer brand. It is employer's duty to create a good engagement activity to retain talented employees in an organization.

\section{REFERENCES}

1. Buckingham, M., \& Coffman, C. "First, break all the rules". New York: Simon \& Schuster, 1999.

2. Childs, Julian.H \& Stoeber, Joachim. "Self Oriented, Other-Oriented and Socially Prescribed Perfectionism in Employees: Relationships with Burnout and Engagement". Journal of Workplace Behavioral Health. Vol. 25(4). Pg: 269-281, 2010.

3. Harter, J.K., Schmidt, F.L. and Hayes, T.L. "Business-unit-level relationship between employee satisfaction, employee engagement, and business outcomes: a meta-analysis". Journal of Applied Psychology, 87. Pg: 268-79, 2012

4. Jyotsna. "Talent management strategy of employee engagement in Indian ITES employees: key to retention". International Journal.Volume:16. Pg:234-345. 2007

5. Konrad, A. M. "Engaging employees through high involvement work practices”. Ivey Business Journal Online. Pg: 1-6, 2006.

6. Knippenberg,B.V et al., Process Orientation versus Outcome-Orientation during Organizational Change: The Role of Organizational Identification. Journal of Organizational. Vol. 27. Pg.: 685-704, 2006.

7. Lockwood, N. R. "Leveraging employee engagement for competitive advantage: HR's strategic role”. SHRM Research Quarterly, 2007.

8. Mamta \& R.Baldev. "Study of Employee Engagement and its Predictors in an Indian Sector". Journal of Service Marketing. Vol. 25(7). Pg: 201, 2011.

9. Otken, A.B \& Erben, G.S. "Investigating the Relationship Between Organizational Identification and Work Engagement and the Role of Supervisor Support". Journal of Economics \& Administrative Sciences. Vol. 12(2). Pg:93-118, 2010.

10. Preeti Thakur. "A Research Paper on the Effect of Employee Engagement on Job Satisfaction in IT Sector". Journal of Business Managament \& Social Sciences Research. Volume 3(5). ISSN:2319-5614, 2014.

11. Robinson, D. Perryman S., and Hayday, S. "The Drivers of Employee Engagement”. Institute for Employment Studies, 2004.

12. Sanford, B. Building a highly engaged workforce: How great manager inspire virtuoso performance. The Gallup Management Journal, 2003.

13. Seigts, G. H., \& Crim, D. "What engages employees the most or, the ten c's of employee engagement”. Ivey Business Journal, 2006.

14. Suhasini and Kalpana.k. "A Study on Factors Affecting Employee Engagement in Indian IT Industry". International Journal of Pure and Applied Mathematics. Vol 118(24). ISSN:1314 - 3395, 2018.

15. Tarique, I., \& Schuler, R. S. "Global talent management: Literature review, integrative framework, and suggestions for further research".
Journal of World Business, 45. Pg: 122-133. doi:10.1016/j.jwb.2009.09.019, 2010.

16. Thiagarajan, B \& Renugadevi, V. "Employee Engagement Practices in Indian BPO Industries-An Empirical Investigation". Interdisciplinary Journal of Contemporary Research in Business. Vol.2( 10). Pg: 134-141, 2011.

17. Victor et al., "The effective design of work under total quality management”. Organization Science.Vol-11. Pg: 1, 2000. 